\title{
New listings share price behaviour on the Johannesburg Stock Exchange
}

\author{
N. Bhana \\ Graduate School of Business, University of Durban-Westville, Private Bag X54001, Durban, 4000 Republic of South Africa
}

Received 13 March 1989; accepted 21 May 1989

\begin{abstract}
The objective of this paper is to determine the price behaviour of new listings on the JSE during the period 1985-1987. The results clearly indicate that those investors who acquired new issues at the initial offering price attained significant short-term benefits in the form of a new issues premium followed by an after-market performance generally supportive of an efficiently operating market. Investors who acquired new issues subsequent to the initial offering earned negative returns (adjusted for market risk as well as systematic risk) during the first year of investment. This investigation reveals that new issues with very large price increases immediately subsequent to their offering do not have returns significantly different from new issues as a whole during the period up to one year following the listing. Investors in the secondary market, on balance, overestimated the return potential and/or underestimated the risk characteristics of new listings on the JSE.
\end{abstract}

Die doel van hierdie ondersoek is om die prysgedrag van nuwe noterings op die Johannesburgse Effektebeurs gedurende die tydperk 1985-1987 te bepaal. Die resultate dui aan dat daardie beleggers wat nuwe uitgifte teen die oorspronklike aanbodprys bekom het, substantiewe korttermynvoordele verkry het in die vorm van 'n nuwe uitgifte-premium gevolg deur 'n nabemarkingsoptrede wat 'n doeltreffend funksionerende mark normaalweg ondersteun. Beleggers wat nuwe uitgifte na die oorspronklike aanbod bekom het, het gedurende die eerste beleggingsjaar negatiewe opbrengste verdien (aangepas vir markrisiko). Hierdie ondersoek bring verder aan die lig dat nuwe uitgifte met buitengewoon hoë prystoenames onmiddellik na hulle aanbieding nie opbrengste verkry het wat noemenswaardig verskil van nuwe uitgifte in die geheel gedurende die tydperk tot en met een jaar na die notering nie. Beleggers in die sekondêre mark, by vergelyking, het die opbrengspotensiaal oorskat en/of die risikokenmerke van die nuwe noterings op die Johannesburgse Effektebeurs onderskat.

\section{Introduction}

The 1985-1987 period witnessed share prices rising to record levels on the Johannesburg Stock Exchange (JSE). In the money market, the prime overdraft rate reached $25 \%$ in early 1985 and this provided an ideal opportunity for highly geared unlisted companies to refinance with low cost equity on the JSE. Furthermore, several companies were undercapitalized as a result of huge foreign exchange losses incurred on uncovered offshore borrowings. Because of the high rate of inflation prevailing during this period, investors became disenchanted with the negative real rates of return provided by traditional money market securities. Consequently, investors began to show a keen interest in share investments as a hedge against inflation. These conditions were ideal for many smaller companies that were not able to satisfy the listing requirements on the main board to seek a listing on the Development Capital Market (DCM) sector of the JSE. The spate of new issues in the DCM sector was largely responsible for the re-emergence of small investors who had avoided the JSE as a result of huge losses suffered in 1969 and 1976.

During this period the investing public displayed a massive appetite for investing in new issues. Many new issues were oversubscribed in excess of a hundred times. Those investors who did not receive sufficient allocations of new issues were prepared to pay huge premiums in the secondary market. For a while, investing in new issues guaranteed profits because of widespread speculation and the rising share market. However, the market crash in October 1987 resulted in the end of the new listing boom. There was a distinct preference for liquidity and investors in new issues incurred huge losses when they liquidated their investments. The purpose of this investigation is to trace the various factors that contributed to the new listings enthusiasm during the 1985-1987 period. The short-term and long-term performance of new listings on the JSE will be evaluated to determine if investors and speculators were able to earn excess returns. Particular attention will be paid to the efficiency of the JSE pricing mechanism in relation to the price behaviour of new issues.

\section{Previous research on the share performance of new listings}

In recent years, several researchers have investigated the price behaviour of new listings. Reilly \& Hatfield (1969) investigated a sample of 53 new issues on the American Stock Exchange (ASE) during the period 1963-1966. Their results support the hypothesis that investors in new share issues enjoy higher short-term returns, on average, than the overall market. It was also observed that while the relative losses in new share issues are small, the relative gains are substantial. Reilly \& Hatfield (1969: 80) concluded that these superior results, on average, can be justified on the basis of the higher risk assumed by the investor acquiring new issues. Aside from the uncertainty regarding future corporate operations, the investor is uncertain regarding the market acceptance of the newly listed shares. Because of the unusually large excess returns in the first week and first month after issue, it can be hypothesized that, even on a risk-adjusted basis, there were substantial positive excess returns during the period of this investigation. 
An investigation by Logue (1973) confirmed that substantial short-term excess returns (up to one month) are obtained by investors subscribing to new issues. It is further suggested that underwriters may attempt to underprice new issues of ordinary shares to encourage both initial subscription to the offering and a successful after-market performance. Block \& Stanley (1980) also observed large positive excess returns in the first week and first month following a new listing. It was suggested that this premium above the issue price can be regarded as a 'rent' that is distributed by underwriters to initial purchasers of shares. It was observed that the short-term positive excess returns did not signify market inefficiency, but rather that the issues were underpriced by the investment bankers when they first went to the market. Jog \& Riding (1987) also found evidence of underpricing in a sample of new issues listed on the Toronto Stock Exchange in Canada.

Several researchers have investigated the price behaviour of new issues in the secondary market. Fabozzi (1981) demonstrated that after the initial new issues premium is established, the market tends to adjust quickly, and subsequent price performance is in accord with market returns. Therefore, if an investor wishes to benefit from a new issue, he or she must generally take a position at the time of issue and not in the secondary market. However, this is a difficult task because the issue may be oversubscribed and allocations may not be made to all prospective investors. McDonald \& Fisher (1972) and Reilly (1973) found slightly negative excess returns from the date of issue to one year later - in spite of positive excess returns in the short-term. Both studies have also observed that a superior short-term performance of a new issue is of no value in predicting the future behaviour of the share price in the long term. Investors acquiring new issues subsequent to the initial offering receive returns during the remainder of the year above the market averages, but these returns appear to be consistent with the higher risk involved.

Bear \& Curley (1975) investigated the pricing behaviour of 140 new issues brought to the market in 1969 , a period of unprecedented new listings on the two major stock exchanges in the United States. The researchers found that the offering price to first market price was significantly different from zero and was positively related to systematic risk. However, the average return from first market price to market price one year hence was $-25 \%$. Bear \& Curley (1975) concluded that their findings do not reject the hypothesis that underwriters of new issues operate competitively and in the best interest of their client firms. The difference between the value the secondary market is willing to pay and the value the firm receives varies in accordance with the firm's risk characteristics.

A major deficiency of the preceding investigations into the new issue price behaviour is that no account is taken of the difference in risk of individual issues and the market portfolio against which they are measured. To overcome this criticism, Ying, Lewellen, Schlarbaum \& Lease (1977) estimated residuals from empirical market lines estimated monthly to measure riskadjusted abnormal returns. Ying et al. found that positive abnormal returns were associated with the 24 months before listing. Although some of the cumulative abnormal return was lost in the post-listing period, the decline was modest in relation to the pre-listing gain. Ibbotson (1975) developed a model to measure the systematic risk for unseasoned securities that were listed on a stock exchange. On a risk-adjusted basis new issues on the two major stock exchanges in the United States (during the 1960s) provided a return of $11,4 \%$ in the first month of listing. The distribution is skewed so that the subscriber of a single random new issue has about an equal chance for gain or loss. Ibbotson (1975:265) concluded that positive initial performance accompanied by after-market efficiency indicates that, generally, new issue offerings are underpriced.

Several hypotheses attempt to explain underpricing of new issues. The simplest amongst these is the 'naive hypothesis'. According to this hypothesis, underpricing represents a risk premium investors demand because the lack of performance history for the new issue increases uncertainty about future performance. As the new issue becomes seasoned, a performance history is established and the risk premium disappears. This explanation, however, is inconsistent with the efficient market hypothesis because it postulates that systematic abnormal returns can be attained in the short term.

Beatty \& Ritter (1986) argued that merchant banks and investment companies associated with a new issue maintain an 'underpricing equilibrium'. They suggest that these agents would lose their share of investors if underpricing were too little, but would lose their market share of issuers if underpricing were too great, given the uncertainty of the issue. These researchers contend that, the greater the uncertainty, the greater the underpricing. New issues must be underpriced, on average, if relatively uninformed potential investors are to be induced to submit bids. Overpricing a new issue can cause future problems for the merchant bank and the issuing company. The market tends to penalize a company whose share price falls below issue price. Such a company acquires a reputation for overselling, which can cause problems later if it again tries to raise capital.

A link between uncertainty and underpricing is also suggested by Rock (1982). It is suggested that relatively uninformed investors (those who do not incur costs of seeking information) are aware that they would tend to receive a greater proportion of overpriced issues (and a lower proportion of underpriced issues) than informed investors would. Accordingly, new share issues must be sufficiently underpriced for uninformed investors to be able to cover the losses resulting from their purchases of overpriced issues. Rock (1982) argued that underpricing is merely compensation to investors for the costs of becoming informed - doing security analysis and so on. And, as might be expected, the greater the fundamental uncertainty about an issue, the greater is the required compensation to investors for becoming informed. In particular, high-risk offerings are, in an expected value sense, underpriced more than other types. The 
appropriate measure of risk in Rock's model of underpricing is not systematic beta-type risk, but the uncertainty uninformed investors have regarding the after-market price.

The 'hot issue' market for new issues of shares to the public are not isolated events. Ibbotson \& Jaffe (1975) observed that in the United States, there have been a number of periods over the last two decades in which initial public offerings of equity capital have provided extremely high returns (stagging profits). Rock's model implies that riskier firms should provide higher average initial returns than firms that are easier to evaluate. This provides a possible explanation for the existence of 'hot issue' markets. If some initial public offerings (low risk) are normally underpriced by only a small amount, and others (high risk) are normally underpriced by a large amount, the average initial return on unseasoned new issues would be higher whenever an unusually large fraction of the initial public offerings were in the highrisk category.

Ritter (1984) analysed the 'hot issue' market covering the 15-month period ending march 1981 in the United States. During this period the average initial return on unseasoned new issues of equity capital was $48,4 \%$ (stagging profits). Ritter (1984:237) observed that for established firms going public, the average initial return was about $15 \%$. For smaller firms a substantially larger initial return of about $71 \%$ was earned. However, underpricing was highest for small firms engaged in high-risk natural resource exploration. For these firms, the average initial return was about $140 \%$ during the 'hot issue' market of 1980. Ritter (1984:239) concluded that the 'hot issue' market of 1980 was an equilibrium phenomenon, explainable by the positive relation between risk and expected initial return. It was also suggested that companies seeking a listing get the best deal by going public immediately ater a 'hot issue' market period of high average initial returns: they receive larger sums for comparatively little equity.

Sanger \& McConnell (1986) reviewed the various studies that have investigated the share price performance of companies that have changed their listing from the over-the-counter (OTC) market to the NYSE. It is reported that shares, on average, earn positive abnormal returns prior to listing and negative returns immediately following the listing. The negative share returns following listing clearly are incompatible with any version of the efficient capital market hypothesis. In order to explain the puzzling pattern in post-listing ordinary share returns McConnell \& Sanger (1987) investigated 2482 shares listed on the NYSE over the period 1926-1982. It was observed that the average market-adjusted returns for the first 12 months following listing are all negative. A common belief among market observers is that investors often overreact to the announcement of major company-specific events. This initial 'overreaction' is then followed by an inevitable 'correction', in which the security's price settles to its 'proper' level. The pattern of observed security prices around listing dates, in which shares earn positive excess returns prior to listing and negative returns following listings, is, on average, consistent with this view. McConnell \& Sanger (1987) showed that none of the various tests performed provide much support for the 'correction of an overreaction' explanation for the puzzle in post-listing share returns.

\section{The new issue market of 1985-1987}

The 1985-1987 period witnessed an unprecedented surge in the number of companies acquiring a listing on the JSE. In particular, 1987 recorded the highest number of new listings in a single year during the 100year history of the stock exchange. The new listings in 1987 by far surpassed the 76 listings established in the previous record year of 1969. A distribution of the new issues during the 1985-1987 period is shown in Table 1 . New issues during the 1985-1987 period can be regarded as 'hot issues' because of the intense speculation in these securities. Besides the large number of new issues, oversubscriptions were common - some issues such as Columbia and SPL were subscribed more than a hundred times the quantity on offer. The massive oversubscriptions guaranteed large scale stagging profits for those investors and speculators who were allocated shares of the new issue. A major feature of the 1985-1987 new issue market was that for the first time since its creation in August 1984, investors showed interest in the Development Capital market (DCM). The DCM was specifically established to give the smaller, entrepreneurial companies, which could not meet the normal stringent rules for listing, an opportunity to raise capital for new development. This, in turn, attracted a new type of investor who was prepared to accept higher risks for the posibility of large returns.

As in the case of the previous new listing boom of 1968-1969, the listing mania of 1985-1987 raised considerable controversy, several investment analysts warned investors of the dangers of applying for new issues without investigating the investment merits of the securities. Kinghorn (1986:486) reported that greed and speculation rather than favourable investment prospects were often the main reasons behind the massive oversubscriptions and hectic trading in new issues. The listing boom of 1968-1969 was followed by a plethora of failures, when many newly listed companies disappeared from the market. However, Glaser (1987) reported a fundamental difference in the quality of companies seeking a listing during the 1985-1987 period compared

Table 1 The distribution of new listings on the JSE during the period 1985-1987

\begin{tabular}{lccc}
\hline Year & Main board & DCM & Total \\
\hline 1985 & 14 & 1 & 15 \\
1986 & 58 & 24 & 82 \\
1987 & 133 & 78 & 211 \\
Total & 205 & 103 & 308 \\
\hline
\end{tabular}


to those listed in 1968-1969. He noted that the listing boom in 1968-1969 had been preceded by strong economic growth. Consequently, it was much easier for a company to establish a track record acceptable to the JSE's listing requirements. By contrast, companies listed during the 1985-1987 period, established their performance record during four years of recession, suggesting a better quality of listing candidates.

The avalanche of new listings revealed a problem related to the ability of the JSE Listing Department to adequately screen all listing applicants. Thompson (1987) reported that the prospectuses of several companies seeking a listing on the JSE contained numerous errors and inconsistencies. Furthermore, these errors had a material bearing on the price of the securities offered. It was also revealed that companies seeking a listing on the DCM sector were often guilty of inadequate disclosure in their prospectuses. The directors are legally responsible for ensuring that information contained in a prospectus is both accurate and sufficiently complete so as not to be misleading. In the case of companies seeking a listing on the DCM sector, the directors are also major shareholders, and therefore, potentially major beneficiaries of the listing. In addition, investors in the DCM are generally smaller investors who are less sophisticated, and have fewer resources than the more professional institutional investors. A further controversy was that many companies did not specify the intended use of the capital raised in their offer documents. Some companies reported in their prospectus that the capital was raised for general development of the company but the funds were used to repay loans from shareholders (Carte, 1987).

Several newly listed companies were guilty of creative accounting whereby the figures in the prospectus have been sanitized by removing the adverse effects of high finance charges, excessive directors' fees, foreign exchange losses, and extraneous trading losses. A justification for this approach is that these items will not recur when the company is listed. Kilalea (1986) showed that many newly listed companies have used the 'continued' and 'discontinued' accounting convention which ignores adverse events and presents only favourable business activities which are to be continued. Carte (1987) indicated that to avoid paying tax, several unlisted companies understate earnings as much as they can. Once they are listed and the high earnings multiple gives them the motive, they can draw on a reserve of understated profits accumulated over several years to produce excellent performance immediately after listing. A similar abuse arises from understating stock values prior to listing and revaluing them after listing.

The spate of new listings has also led to abuse of generally accepted accounting practice related to acquisitions and disposals of subsidiaries. The results of recently acquired companies in the group were added together irrespective of whether or not they had been part of the group for the period covered by the financial statements. This approach has misled investors in that earnings and the growth rate are inflated. Everingham
(1988) reported that a perusal of the financial statements of newly listed companies, particularly in the DCM sector, indicates widespread abuse of backdating acquisitions and disposals of subsidiaries. Many small investors and speculators have invested in these companies on the basis of illusory growth and unrealistic earnings forecasts. Oosthuizen (1987) reported that several companies intentionally timed the announcements of acquisitions to coincide with their listings. This attempt can be seen as a deliberate attempt to influence the share price and marketability of the shares.

Most new issues during the 1985-1987 period opened at a huge premium over their issue price. This suggests that many new listings were priced too low. Wengrowe (1986) reported that in many cases the issue price was deliberately kept low. As only a small portion of the equity was sold to outsiders, the long-term public relations and marketing mileage gained from giving a handful of investors a quick capital gain outweighed the prejudice to the company of giving away its shares too cheaply. Another reason for underpricing is to retain trained staff the company depends on, this can be achieved by offering them shares in the company at low prices. However, the level of underpricing must be kept in perspective. Newly listed companies deliberately underprice to ensure a successful listing. 'Pitch it low, make it go' is an old adage on the NYSE. Many companies that listed during this period were small (high-risk) companies in the early stages of their development. These companies had to offer investors adequate risk premiums for the uncertainty during the post-listing period.

\section{New issue share price behaviour on the JSE}

The purpose of this study is to investigate the price behaviour of new issues of shares immediately following the offering and over the subsequent year during the period 1985-1987. It can be expected that underwriters may attempt to 'underprice' new issues of ordinary shares so that the initial offering will be fully subscribed and rise in price subsequent to the issue. The theory of efficient markets suggests that the price of new issues will quickly adjust to reflect the available set of relevant information. To the extent that underpricing exists, the difference between offering price and subsequent market price constitutes a 'rent' that is distributed by the underwriters to initial purchasers of the shares. It is hypothesized that this rent, viewed here as an initial rate of return' was significantly positive during the 1985-1987 study period.

If the efficient market model is applicable to the JSE new share issues, subsequent price behaviour of the shares should be independent of the initial rate of return at offering. Such independence is not unanimously accepted. For instance, Reilly \& Hatfield (1969) have suggested that the short-term price adjustment after the offering could be continued through the long term as the market continues to recognize and adjust for the underpricing. Their conclusion is that issues which 
increase in price in initial trading also tend to have greater than average returns over the next year. As many new issues are oversubscribed, it is this subsequent price behaviour that is important to the majority of investors who must buy at the market price rather than at the offering price. Carte (1986) analysed the price behaviour of new issues on the JSE during 1986 and alluded to the possible dependence in returns over time. It was suggested that widespread speculation in the new issue market is self-generating; a sharp rise in price often creates demand for an issue. The alleged persistence of price changes over time whether expressed in terms of buying or selling pressure, momentum, or waves of investor exuberance generally reflects a view of capital markets different from the efficient market model.

\section{Sample and research methodology}

The sample comprises 80 new equity issues ( 40 on the main board and 40 on the DCM) listed on the JSE during the 1985-1987 period (see Appendix A). The price movements of these shares are observed from the time of first listing to a period of one year after listing. First, the analysis is presented on a non-risk adjusted basis because of the difficulty of applying risk-adjusted models to new issues in view of the absence of prior data. An excess return, $U_{j t}$ is computed for each share in each period:

$U_{j t}=R_{j t}-R_{m t}$

where $U_{j t}=$ excess return; $R_{j t}=$ return on share $j$ in period $t$; and $R_{m t}=$ return on the JSE Overall Actuaries Index.

The general problem of adjusting for market-wide movements in security prices on individual share returns has received considerable attention. One useful procedure is to estimate parameters of the SharpeLintner-Mossin capital asset pricing model developed by Bowman (1983). According to this model, the residual in each period, is the 'abnormal return' for share $j$ :

$R_{j t}=a_{j}+b_{j} R_{m t}+e_{j t}$

As the data files in the present study contains very few observations of price for each new issue, estimation of coefficients $a_{j}$ and $b_{j}$ for each security was not practicable. As a useful ad hoc adjustment for the market effects on new issue returns, the difference between security and market returns is computed in equation (1), where the JSE Overall Actuaries Index is representative of the entire population from which new issues are drawn. If for each new issue share, $a_{j}$ equals zero and $b$, equals one in equation (2), that is if the nondiversifiable risk of each new issue is the same as that of the market average, then equation (1) is consistent with the capital asset pricing model. One would expect, however, that inter-company differences in $b_{j}$ exist among recent offerings and that the average $b_{j}$ of new issues exceeds one, i.e., that most new issues are 'riskier' than the market average. The result, then, is that the transformation of share returns to excess returns in equation (1) serves to adjust roughly for the market effects on new issue returns to investors.

The sample mean 0 , may be viewed as a performance index which reflects the return, in excess of the JSE market return. If underpricing of new issues exists, one would expect significantly positive value of the initial rate of return $\bar{U}_{0.1}$, the, average change in price from the offering price to the first published market price, adjusted for market effects. The efficient market hypothesis suggests that subsequent market price behaviour should be independent of the initial price change after the offering. To test this hypothesis, the sample is partitioned by initial price adjustment $\bar{U}_{0-1}$ to identify shares whose prices increased by $100 \%$ or more immediately following the listing. In an efficient market the subsequent performance of these subsamples of 'hot issues' purchased immediately after listing and held for a period of one year, should not be significantly different from the average return during the same period for the whole sample of new issues. In general, one would not expect information on the price behaviour immediately subsequent to the offering to be of any value in selecting shares that are likely to outperform the market.

\section{Empirical results}

For each company in the sample, excess returns reflecting percentage share price changes adjusted for market movements, were measured one week, one month, and one year after listing and are shown in Table 2.

Of particular interest are the high values $(65,6 \%$ and $68,5 \%$ for the main board and the DCM respectively) of the difference between the issue price and the share price at the end of the first day's trading $\left(\bar{U}_{0-1}\right)$. These results suggest that those speculators (stags) who sold their share allocations shortly after listing obtained huge stagging profits. This clearly indicates that, on average,

Table 2 Data on excess returns for a sample of 80 new issues listed on the JSE during 1985-1987 (based on the issue price of shares)

1 Week 1 Month 1 Year

\begin{tabular}{lccc}
\hline Main board: $\bar{U}_{0-1}=65,6 \%$ & & & \\
Mean $\left(\bar{U}_{t}\right)$ & $69,7 \%$ & $66,6 \%$ & $50,3 \%$ \\
Standard deviation & 55,6 & 64,2 & 88,7 \\
Coefficient of variation & 0,80 & 0,96 & 1,76 \\
Pearsons skewness & 1,78 & 1,67 & 0,94 \\
$t$ value & 3,87 & 3,62 & 3,20 \\
Development capital market: & & & \\
$\bar{U}_{0-1}=68,5 \%$ & & & \\
Mean $\left(U_{t}\right)$ & $74,3 \%$ & $71,7 \%$ & $55,3 \%$ \\
Standard deviation & 61,8 & 69,3 & 92,3 \\
Coefficient of variation & 0,83 & 0,97 & 1,67 \\
Pearsons skewness & 1,82 & 1,73 & 1,04 \\
$t$ value & 3,92 & 3,59 & 3,14 \\
\hline
\end{tabular}


new issues during the study period were substantially underpriced. There are noticeable excess returns in the first week after listing $(69,7 \%$ and $74,3 \%$ for the main board and DCM respectively), with the pattern highly skewed to the right as indicated by a Pearsonian coefficient of skewness figure of 1,78 for the main board and 1,82 for the DCM. This supports the contention that losses on new issues are limited, while some new issues perform exceptionally well. The $69,7 \%$ and $74,3 \%$ excess returns in the first week are statistically significant in the sense that we can reject at the 0,99 level the null hypothesis that the true excess return in the first week is zero.

The excess returns for the one-month and one-year holding periods are also positive and statistically significant at the 0,99 level for listings on both the main board and the DCM. The excess returns show a decreasing tendency with the passage of time. The data presented in Table 2 actually indicate that the excess returns for the longer periods are only positive because of what transpired during the first week. In particular, the one-time 'rent' distributed by the underwriter to his clients as initial purchasers of the offering, is the prime reason for excess returns in the short term (one week and one month) and long term (one year). A noteworthy result was that the average new issue price change from offering date to a period of one month after issue was less than the corresponding price change for the first week after the offering date. This would indicate that the bulk of the very short-term adjustment was accomplished almost immediately after the offering.

Most investors do not have the opportunity to acquire sufficient quantities of new issues at the offering price as the shares are oversubscribed many times. Therefore, they are obliged to acquire additional quantities in the secondary market. In order to examine the effects of this

Table 3 Data on excess returns for a sample of 80 new issues listed on the JSE during 1985-1987 (based on the closing price at the end of the first day of listing)

\begin{tabular}{lccc}
\hline & 1 Week & 1 Month & 1 Year \\
\hline Main board: & & & \\
Mean $\left(\bar{U}_{t}\right)$ & $1,8 \%$ & 2,6 & $-11,3 \%$ \\
Standard deviation & 12,7 & 20,2 & 38,7 \\
Coefficient of variation & 7,06 & 7,77 & 3,42 \\
Pearsons skewness & 0,29 & 0,37 & $-0,74$ \\
l value & 0,90 & 1,17 & $-1,93$ \\
Mean (shares that opened at a & & & \\
premium greater than $100 \%$ ) & $2,21 \%$ & $3,26 \%$ & $-12,52 \%$ \\
Development capital market: & & & \\
Mean ( $\bar{U}_{t}$ ) & $2,6 \%$ & $3,2 \%$ & $-20,8$ \\
Standard deviation & 15,9 & 24,8 & 43,6 \\
Coefficient of variation & 6,11 & 7,75 & 2,10 \\
Pearsons skewness & 0,41 & 0,48 & $-1,23$ \\
$t$ value & 1,18 & 1,28 & $-2,21$ \\
Mean (shares that opened at a & & & \\
premium greater than $100 \%$ ) & $3,15 \%$ & $4,52 \%$ & $-25,5 \%$ \\
\hline & & & \\
\hline
\end{tabular}

contention, the previous samples were examined using post-offering prices. Specifically, it was assumed that all new issues were acquired at the price ruling at the end of the first day of listing and were held for durations of one week, one month and one year after acquisition. The market-adjusted excess returns for the different holding periods are presented in Table 3.

The results in Table 3 clearly illustrate that shares of newly listed companies acquired in the secondary market do not provide superior performance. While slightly positive excess returns are attained for holding periods of one-week and one-month after purchase, these results are not statistically significant. However, statistically significant negative excess returns at the 0,95 level were found for the one-year holding period. To the extent that the majority of new issues have greater systematic risk than the market average, it can be concluded that these securities produced negative returns on a risk-adjusted basis. Payne (1988) reported that the market for new issues was exceptionally active until July 1987 and then began to lose momentum, and at the time of the market crash in October 1987 the listing mania came to an abrupt end. In the period following the market crash the enthusiasm for new listings disappeared. Because of the negative market sentiment many listings were not fully subscribed and several opened at a discount to their issue prices. As a result new issues underperformed the market during this period of negative market sentiment. The underperformance of new listings on the DCM was particularly pronounced. This is due to the high-risk nature of companies on the DCM sector. During the buoyant market conditions preceding the October 1987 market crash, prices of new listings on the DCM rose more steeply than the rest of the market. However, after the market crash the DCM underperformed the rest of the market. This observation is confirmed by Payne (1988:32) who showed that the DCM's speculative profile and the relative unattractiveness in a bear market has resulted in investors losing confidence in this sector after the October 1987 market crash.

Of particular interest is the after-market performance of new issues that opened at a premium of greater than $100 \%$ on their issue prices. The results in Table 3 reveals that new issues with very large price increases immediately subsequent to their offering do not have returns significantly different from new issues as a whole during the period up to one year following the listing. The findings in this study are consistent with the efficient market view, as one cannot reject the hypothesis that issues with high initial rates of return immediately following the offering, have rates of return for the first year equivalent to that of the entire population of new issues. As early price behaviour has no value in predicting later behaviour, new issues purchased at the prevailing market price, immediately following the offering for example, should be viewed in the same framework as other securities where differences in expected returns are attributed primarily to differences in risk. 
The results of this study clearly indicate that those investors who acquired new issues at the offering price attained significant short-term benefits in the form of new issues premium, followed by an after-market performance generally supportive of an efficiently operating market. The fact that the new issues yield positive excess returns in the short term does not signify market inefficiency, merely that the issues were underpriced by the merchant bankers/brokers when they first went to the market. The efficient market pricing mechanism, however, takes over very quickly. Investors who acquired new issues in the secondary market received negative returns for a one-year holding period, but these results appear to be associated with a market correction for the initial overreaction which resulted in many shares opening way above the issue price.

Newly listed companies can be expected to have a higher risk than the average market risk. Therefore, the preceding analysis is deficient in that the actual riskadjusted returns have not been calculated. In particular, it can be stated that the results are overstated by not taking the higher risk of unseasoned securities into consideration. The traditional Market Model cannot be used to calculate the risk-adjusted returns for new issues. Ibbotson (1975) showed that the systematic risk of new issues is greater than the systematic risk of the market, and the systematic risk of securities is not stable in that it decreases as the securities become seasoned. To overcome the inapplicability of the Market Model, a technique to calculate the risk-adjusted returns proposed by Ying et al. (1977) can be used. They contended that the instability of the beta of a security can be overcome by forming benchmark portfolios to represent the empirical risk-return market relationship, using the estimated betas of one time period, but then computing a revised set of betas for that relationship from data covering a subsequent period.

The technique proposed by Ying et al. (1977) was used to calculate the risk-adjusted returns for the sample of firms investigated. For each of the 80 sample firms whose shares were listed on the JSE during the 1985-1987 period, monthly returns were calculated for a period of 12 months after listing. The initial price for each security is the closing price prevailing at the end of the first day of listing. The 'excess' or 'residual' returns realized by the securities, i.e. that component of return not attributable to general market movements, were compiled for all 80 securities, for the immediate 12 months following the listing. The common benchmark date $(t=0)$ for the analysis for every security is the month of its listing. Thus, a variety of different calendar periods are encompassed within the investigation intervals $t=+1$ to +12 . The residual returns represent the risk-adjusted monthly returns earned by an investor who acquired the new issues immediately after they were listed on the JSE. The empirical results are contained in Table 4.

The average risk-adjusted returns for the first month following listing are positive $(0,82 \%$ for the main board and $0,94 \%$ for the DCM). However, these results are not statistically significant. Furthermore, these are the
Table 4 Monthly risk-adjusted returns, for a sample of new listings on the JSE during 1985-1987 (figures in percentages)

\begin{tabular}{|c|c|c|c|c|}
\hline \multirow[b]{2}{*}{ Month $^{\mathbf{a}}$} & \multicolumn{2}{|c|}{ Main board } & \multicolumn{2}{|c|}{ Development capital market } \\
\hline & $\begin{array}{c}\text { Mean } \\
\text { Monthly } \\
\text { Residual }\end{array}$ & $\begin{array}{l}\text { Cumu- } \\
\text { lative } \\
\text { Residual }\end{array}$ & $\begin{array}{c}\text { Mean } \\
\text { Monthly } \\
\text { Residual }\end{array}$ & $\begin{array}{l}\text { Cumu- } \\
\text { lative } \\
\text { Residual }\end{array}$ \\
\hline 1 & $0,82^{b}$ & 0,82 & 0,94 & 0,94 \\
\hline 2 & $-2,36^{\mathrm{c}}$ & $-1,54$ & $-3,32^{c}$ & $-2,38$ \\
\hline 3 & $-1,93^{c}$ & $-3,47$ & $-2,87^{c}$ & $-5,25$ \\
\hline 4 & $-1,86^{\mathrm{c}}$ & $-5,33$ & $-3,41^{c}$ & $-8,66$ \\
\hline 5 & $-2,01^{\mathrm{c}}$ & $-7,34$ & $-2,43^{\mathrm{c}}$ & $-11,09$ \\
\hline 6 & $-1,72^{\mathrm{c}}$ & - 9,06 & $-1,34^{d}$ & $-12,43$ \\
\hline 7 & $-1,36^{d}$ & $-10,42$ & $-1,97^{c}$ & $-14,40$ \\
\hline 8 & $-1,88^{c}$ & $-12,30$ & $-2,82^{c}$ & $-17,22$ \\
\hline 9 & $-0,76$ & $-13,06$ & $-3,41^{\mathrm{c}}$ & $-20,63$ \\
\hline 10 & $-1,47^{d}$ & $-14,53$ & $-2,86^{\mathrm{c}}$ & $-23,49$ \\
\hline 11 & $-1,93^{c}$ & $-16,46$ & $-2,52^{\mathrm{c}}$ & $-26,01$ \\
\hline 12 & $-1,86^{\mathrm{c}}$ & $-18,32$ & $-3,14^{c}$ & $-29,15$ \\
\hline
\end{tabular}

Month $t=0$ is the month of listing

' Read: The mean observed return on the sample of securities, during the month after listing, was $0,82 \%$ above that attributable to general market returns, given the level of systematic risk of the securities involved

Two-tailed test at the 0,05 and 0,10 level of significance denoted by ${ }^{c}$ and $d$ respectively

only positive risk-adjusted returns over the one-year period following the listing. Negative risk-adjusted returns are observed for the succeeding 11 months. These results confirm the results in Table 3, which showed that investors acquiring new issues in the aftermarket attain positive excess returns (adjusted for the market) up to a period of one month and then earn negative returns in the long term. The risk-adjusted returns are substantially lower than the excess returns adjusted for the market risk. On a cumulative basis, the one-year residual returns are $-18,32 \%$ and $-29,15 \%$ for the main board and the DCM respectively. These results were no doubt influenced by the market crash in Ocober 1987. These results also confirm that the market correction was much more severe on the DCM than the main board. These results also suggest that during the new listing mania of 1985-1987 investors in the secondary market, on balance, overestimated return potential and/or underestimated risk characteristics of new listings on the JSE.

No plausible explanation can be offered for the poor performance of the sample of new issues during the oneyear period immediately after the listing. A common belief among several market observers is that investors often overreact to the announcement of major corporate events (De Bondt \& Thaler, 1985). This initial 'overreaction' is followed by an inevitable 'correction', in which the security's price settles to its 'proper' level. It is contended that the huge premiums accompanying a 
listing during the study period can be regarded as an overreaction to the favourable news associated with the market listing. The pattern of observed security prices around the listing dates, in which shares earn positive excess returns immediately upon listing and negative excess returns for a period up to 12 months, is on average, consistent with the overreaction hypothesis. The predominance of negative risk-adjusted returns for roughly a year is a low-likelihood phenomenon in an efficient market. Such evidence reinforces the notion that a secular correction was occurring.

\section{Conclusion}

In this study, a number of hypotheses based on the efficient market model were tested with the data on 80 new listings of ordinary shares on the JSE during the 'hot issue' period of 1985-1987. The findings indicated significantly large returns for the initial subscribers, adjusted for the market effects, in the period up to one month following the initial offering. Investors who acquired new issues subsequent to the offering earned negative returns (adjusted for market risk as well as systematic risk) during the first year of investment. The evidence supports the efficient market notion of rapid adjustment of prices to available information, so that subsequent returns from the time of listing to one year after the listing were not different for issues with large initial price increases compared with returns on new issues as a whole. The implication is that short-term holdings were highly profitable to initial subscribers, but that initial price behaviour did not have significant predictive value to investors making purchasing decisions in the secondary market a short time after the offering.

During the study period, widespread speculation occurred in the market for new listings on the JSE. During the early period (1985-1986) new issues outperformed the market. However, a levelling-off in demand for new issues followed in mid-1987; shortly thereafter, the market collapsed in October. Investors were forced to accept large price declines to offload the new issues which were now neglected by the market. As a result of the collapse of the market, investors who had paid huge premiums for new listings in the secondary market incurred substantial losses. The market for new issues was based more on speculation and rumours than on investment fundamentals. Investors appeared to have overestimated the return potential and/or underestimated the risk characteristics of new listings.

\section{References}

Bear, R.M. \& Curley, A.J. 1975. Unseasoned Equity Financing. J. Finan. Quant. Anal., vol. 10, 311-326.

Beatty, R.P. \& Ritter, J.R. 1986. Investment Banking, Reputation and the Underpricing of Initial Public Offerings. J. Finan. Econ., vol. 14, 312-322.

Block, S. \& Stanley, M. 1980. The Financial Characteristics and Price Movement Patterns of companies Approaching the Unseasoned Securities Market in the Late 1970's. Finan. Manage., vol. 9, 30-36.
Bowman, R.C. 1983. Understanding and Conducting Event Studies. J. Bus. Fin. Account., vol.10, 561-584.

Carte, D. 1986. High ride on boom for JSE's new boys. Bus. Times, September 14, 1-3.

Carte, D. 1987. New listings - traps for the unwary. Bus. Times, September 13, 36.

De Bondt, W.F. \& Thaler, R.H. 1985. Does the Stock Market Overreact? J. Fin., vol. 40, 793-805.

Everingham, G.K. 1988. Escaping Reality Accounting Conventions, Conceptions and Comparability. Unpublished Inaugural Lecture, University of Cape Town. 24p.

Fabozzi, F.J. 1981. Does listing on the AMEX increase the value of equity? Finan. Manage., vol. 10, 43-50.

Glaser, N. 1987. New listing - cashing in. Top Companies, Supplement to Financial Mail, May 22, 41-45.

Ibbotson, R.G. 1975. Price Performance of Common Stock New Issues. J. Finan. Econ., vol. 2, 235-272.

Ibbotson, R.G. \& Jaffe, J.F. 1975. Hot Issues Markets. J. Fin., vol.30, 1027-1042.

Jog, V.M \& Riding, A.L. 1987. Underpricing in Canadian IPOs. Finan. Anal. J., vol. 43, 48-55.

Kilalea, D. 1986. Time for caution? Fin. Week, October 9-15, vol. 31, 133-140.

Kinghorn, F. 1986. Paper chase - oversubscriptions have reached crazy proportions. Fin. Week, November 13-19, vol. $31,486$.

Logue, D.E. 1973. On the pricing of unseasoned equity issues: 1965-1969. J. Finan. Quant. Anal., vol.8, 91-103.

McConnell, J.J. \& Sanger, G.C. 1987. The puzzle in post-listing common stock returns. J. Fin., vol. 42, 119-140.

McDonald, J.G. \& Fisher, A.K. 1972. New-issue stock price behaviour. J. Fin., vol. 27, 97-102.

Oosthuizen, L. 1987. Motoring the shares - suspicions of disclosure in prospectuses being less than adequate. Fin. Week, August 6-12, vol. 34, 321.

Payne, T. 1988. Development Capital Market - the struggle continues. Finan. Mail, August 26, vol. 109, 31-34.

Reilly, F.K. \& Hatfield, K. 1969. Investor experience with new stock issues. Finan. Anal. J., vol. 25, 73-80.

Reilly, F.K. 1973. Further evidence on short-run results for new issue investors. J. Finan. Quant. Anal., vol. 8, 83-90.

Ritter, J.R. 1984. The "hot issue" market of 1980. J. Bus., vol. 57, 215-240.

Rock, K.R. 1982. Why new issues are underpriced. Unpublished Ph.D dissertation, University of Chicago.

Sanger, G.C. \& McConnell, J.J. 1986. Stock exchange listing, firm value and security market efficiency: the impact of NASDAQ. J. Finan. Quant. Anal., vol. 21, 1-25.

Thompson, B. 1987. New listings - weaknesses in the system. Finan. Mail, May 8, vol. 104, 96-97.

Wengrowe, L. 1986. Parable of new listings. Bus. Times, November 9, 2.

Ying, L.K., Lewelłen, W.G., Schlarbaum, G.G. \& Lease, R.C. 1977. Stock exchange listings and securities returns. $J$. Finan. Quant. Anal., vol. 12, 415-432. 
Appendix A Companies included in the sample to investigate price behaviour of new listings on the JSE

\begin{tabular}{|c|c|}
\hline Advanced Technical Systems L.id. & Morkels Ltd. \\
\hline Allied Group Lid. & Ohio Group Ltd. \\
\hline Barlow Rand Properties Lid. & Prestige Group Lid. \\
\hline Bolton Industrial Holdings Ltd. & Racy Group Holdings Ltd. \\
\hline Brenner Mills Lid. & Reichmans Ltd. \\
\hline Cashbuild Ltd. & Rusfurn Group I.td. \\
\hline Computermatic Holdings Ltd. & Skirtskip Clothing I.td. \\
\hline CRB Holdings L.Id. & Smith Mining Equipment Lid. \\
\hline Crown Food Holdings Ltd. & Southern Life Assurance Ltd. \\
\hline Dimension Data Holdings Ltd. & Spescom Electronics L.td. \\
\hline Funa Foods Ltd. & SPI. I.Id. \\
\hline Hi-Score Lid. & Technihire L.td. \\
\hline Hudaco Industries. & Time Holdings Ltd. \\
\hline Hunts L.td. & Titaco Consolidated Investment Lid. \\
\hline Iloo Homes Ltd. & Transkei Sun International Ltd. \\
\hline Lifegro Assurance L.td. & Transvaal Clothing Industries LId. \\
\hline Lithosaver Sysiems I.td. & United Building Society Ltd. \\
\hline Lovasz Chemicals L.td. & Unitrans Lid. \\
\hline Mercedes Datakor Ltd. & Video Lab Holdings L.td. \\
\hline Milstan Holdings Ltd. & Yelland Technology Holdings I.td. \\
\hline
\end{tabular}

\section{Appendix A Continued}

Dewelopment capital merket

Aimark Holdings Ltd.

Ancom Jet Aviation Led.

Audiodek Hokdings Led.

Automated Office Systems Ltd.

Bakoven I.td.

Bloch Lid

Blue Marlin Holdings Lid.

Canvacor Lid

Cashworths Fashion Holdings Ld

Citizen Holdings Lıd

Deale \& Hutch Holdings L.td.

Don Gray Computer Holdings Lid.

Dukel Holdings Ltd.

Elex Electronics Lid.

Fincord Statmeners Ltd.

Furniture Fair Lid.

IEM Products LId.

Jaqmar Holdings Lid

Juicy Lucy (SA) Ltd

Leppin Holdings Lud
Maxmech Mechanical Scals Lid

Meter Systems Lid.

Mighty Meat Holdings Lid

Mike's Kitchen Franchising LAd.

Milly's Stores L.td.

Mynkar Hotdings Lud.

Pactape I.td

Pals Holdings I.td

Playtime Holdings Lid.

Pointer Fashion Intemational Led.

President Medical Investment Ldd.

Public Safety Systems Idd

Quantum Group Lid.

Sasfin Holdings I.Id

Sokthem Invesiment Hoddings Lud.

Spicer-Mitchell Holdings Lud

Spur Holdings LId.

Transvaal Mining Supply Co. Led.

Unitech Computer Group Lid

Work of Music Holdings Ld. 